\author{
Roman Fedan \\ Zakład Przedsiębiorczości i Gospodarki Przestrzennej \\ Instytut Geografii \\ Akademia Pedagogiczna, Kraków
}

\title{
Rola przedsiębiorczości w aktywizacji ośrodków ponadlokalnych (na przykładzie Jarosławia)
}

Przedsiębiorczość w najszerszym ujęciu obejmuje trzy podstawowe elementy tj. pojęcie przedsiębiorcy, działania przedsiębiorcze oraz przedsiębiorstwo jako organizację przedsiębiorczą.

Pod pojęciem przedsiębiorcy kryją się ludzie rozpoczynający działalność gospodarczą nastawioną na zysk, a więc prowadzący interesy na własny rachunek i całkowicie odpowiedzialni za efekty swojej działalności. Osoby te wykorzystują zaistniałe warunki tj. szanse i okazje pojawiające się w ich otoczeniu. Starają się oni wprowadzić jak najwięcej zmian, podejmując działania innowacyjne i przetwarzają otaczającą ich rzeczywistość, niezależnie od posiadanych zasobów i środków. Według P. Druckera (1992) przedsiębiorca to człowiek, który nabywa środki produkcji i wykorzystuje je do wytwarzania wprowadzonych na rynek produktów. Uważa on przedsiębiorcę za człowieka poszukującego zmian i odpowiedzialnego za nie, a także wykorzystującego je jako swoją szansę.

$\mathrm{W}$ inicjowaniu procesów przedsiębiorczych wiodąca rola przypada ludziom o określonych predyspozycjach psychoosobowych. Z. Makieła i T. Rachwał $(2002,2005)$ uważają, że człowiek przedsiębiorczy potrafi kreować nowe potrzeby dla siebie i innych, a także zaspakajać je niezależnie od warunków otoczenia.

A zatem przedsiębiorczość to zespół określonych cech osobowych człowieka, które pozwalają mu aktywnie uczestniczyć w życiu społeczno-gospodarczym. Wyzwolona W określonym środowisku aktywność społeczna, wspomaga zagospodarowanie przestrzenne i aktywizuje dany obszar lub ośrodek osadniczy. To właśnie miejscowe siły endogeniczne przy wsparciu działań zewnętrznych przyspieszają rozwój społeczno-gospodarczy danego terenu.

Przedsiębiorczość uważana jest przez ekonomistów za jedną z podstawowych kategorii ekonomicznych takich jak praca, ziemia i kapitał. Jest ona naturalnym podłożem gospodarki rynkowej. Konkurencyjny charakter gospodarki rynkowej ze swojej natury zmusza do zachowań przedsiębiorczych (Penc 1999). Nadzieją i zarazem jedyną szansą gospodarki rynkowej w Polsce jest oparcie jej na przedsiębiorczości i przedsiębiorcy.

Lata dziewięćdziesiąte $\mathrm{w}$ literaturze przedmiotu nazywane są okresem eksplozji przedsiębiorczości, który charakteryzuje się przyrostem liczebności firm prywatnych i przechodzącym w okres samoregulacji rynkowej. W okresie tym słabe firmy lub firmy wadliwie zarządzane upadają i ulegają likwidacji albo zawieszają swoją działalność (Piasecki 1992). Ale równocześnie zamiast nich szybko pojawiają się nowe firmy, często o innym rodzaju działalności, powodując $w$ rezultacie zmianę struktury branżowej firm. 
Kolejna faza rozwoju przedsiębiorczości i faza restrukturyzacji, charakteryzuje się adaptacją do nowych warunków ekonomicznych oraz poszukiwaniem nowych najczęściej zewnętrznych źródeł finansowania. Jednakże zarówno rozwój ilościowy jak i dojrzewanie struktury branżowej, a także restrukturyzacja ekonomiczno-rynkowa nie byłyby możliwe bez polityki państwa wspierającej rozwój przedsiębiorczości i kształtującej warunki tego rozwoju (Piasecki 1992).

\section{JAROSLAW NA MAPIE GOSPODARCZEJ REGIONU}

Rozwój gospodarczy i urbanizacyjny miasta ściśle związany był z bardzo dogodną lokalizacją na szlaku dróg komunikacyjnych oraz z fazą industrializacji jaka objęła kraj na przełomie lat 60 -tych i 70-tych, jak również z procesem transformacji gospodarki zapoczątkowanym w latach 90-tych ubiegłego wieku.

Jarosław położony jest przy bardzo ważnym korytarzu transportowym, który tworzą międzynarodowa droga E40, a w krótkiej perspektywie czasu autostrada A4 oraz dwutorowa zelektryfikowana linia kolejowa Nr 30, łączącym Europę zachodnią wzdłuż pogórza Sudetów i Karpat z obszarami zachodniej Ukrainy i dalej w kierunku Odessy i Rumunii. Na trasie tego korytarza przy granicy polsko - ukraińskiej, kształtuje się międzynarodowy węzeł transportowy Medyka-Szeginie i Przemyśl-Mościska, który z przejściami granicznymi Kroscienko-Smolnica i Korczowa-Krakowiec tworzy zespół przejść granicznych o charakterze funkcjonalno-przestrzennym, określanym w literaturze „terytorialnym węzłem komunikacyjnym" (Rościszewski 1997). Jest to zatem lokalizacja o wymiarze wybitnie tranzytowym, która stwarza dodatkowe możliwości wzrostu gospodarczego miasta, wynikające z jego przygranicznego położenia przy bardzo ważnym szlaku komunikacyjnym kraju, prowadzącym do przejścia granicznego w Korczowej na terenie administracyjnym powiatu jarosławskiego.

Stąd też infrastruktura transportowa o wymiarze transgranicznym wywiera znaczący wpływ na wzrost pozycji społeczno-gospodarczej miasta jako ośrodka subregionalnego. Wzrost ten kształtowany jest miedzy innymi poprzez lokalizację, a następnie rozwój podmiotów gospodarczych o zasięgu regionalnym i ponadregionalnym.

Bardzo sprzyjającym okresem w rozwoju miasta Jarosławia, był proces przyspieszonej industrializacji kraju rozpoczęty pod koniec lat 60 -tych ubiegłego wieku. W czasie trwania gospodarki centralnie sterownej, zlokalizowano w mieście dwie nowe inwestycje przemysłu mineralnego i lekkiego, a to Hutę Szkła opakowaniowego i Zakłady Dziewiarskie „Jarlan”, należące do największych fabryk w tych branżach w Polsce. Jednocześnie do 1975 roku powiększono moce produkcyjne i zmodernizowano trzy przedsiębiorstwa przemysłu spożywczego tj. Zakłady Przemysłu Mięsnego, Zakłady Przemysłu Cukierniczego „San” i Zakłady Zbożowo-Młynarskie. W wyniku tych działań nastąpił bardzo szybki wzrost potencjału produkcyjnego w mieście, prezentującego nowoczesny profil produkcji, a zwłaszcza w branży dziewiarskiej i szklarskiej.

W 1975 roku w wiodących zakładach przemysłowych miasta zatrudnionych było około 10 tys. osób na 18,5 tys. pracujących ogółem.

Był to czas forsownej industrializacji miasta otoczonego obszarami rolniczymi, o rozproszonym osadnictwie wiejskim, a zwłaszcza we wschodniej i północnej części powiatu. W następstwie tego procesu zauważono określone zmiany, a to:

- gwałtowny wzrost miejsc pracy, a szczególnie produkcyjnych, w wyniku czego nastąpił przyspieszony proces przyuczania ludzi do wykonywania nowych zawodów,

- radykalne zmiany w profilach kształcenia młodzieży na poziomie szkół zasadniczych zawodowych i techników,

- $\quad$ szybki rozwój grupy chłopo-robotników w ogólnym zatrudnieniu, a zwłaszcza w zakładach produkcyjnych, 
- przyspieszony rozwój budownictwa spółdzielczego zakładowego i komunalnego, który uruchomił proces urbanizacji miasta i spowodował wzrost usług w dziedzinie: handlu, ochrony zdrowia, oświaty i kultury,

- powiększanie się zjawiska dojazdów do pracy (w tym zakładowymi środkami lokomocji), co przyczyniło się do powołania miejskiej komunikacji samochodowej.

Tab. 1. Zatrudnienie w zakładach przemysłowych w Jarosławiu.

\begin{tabular}{|l|c|c|}
\hline Nazwa zakładu & 1975 r. & 2003 r. \\
\hline ZPDz. „Jarlan” & 3442 & 1056 \\
Huta Szkła & 1586 & 646 \\
ZPC „San” & 1547 & 524 \\
Zakłady Mięsne & 1384 & 612 \\
Zakłady Zbożowo - Młynarskie & 956 & - \\
Jarosławskie Przedsiębiorstwo Budowlane & 783 & 356 \\
\hline Razem & 9698 & 3194 \\
\hline
\end{tabular}

Źródło: Dział kadr przedsiębiorstw.

Przytoczone wskaźniki dla 1975 roku są potwierdzeniem przyspieszonego procesu industrialnego miasta, który stał się głównym czynnikiem miastotwórczym, stymulującym jego rozwój gospodarczy, społeczny i oświatowo - kulturalny. Proces ten wykształcił chłonny subregionalny rynek pracy, który wytworzył silne powiązania z bliższym i dalszym jego zapleczem. Na spójny proces industrializacji i urbanizacji jako drogi rozwoju gospodarczego nie tylko miast ale także regionów, w literaturze przedmiotu zwraca uwagę wielu autorów.

Do końca lat 80-tych na miasto Jarosław przypadało około $60 \%$ ogółu potencjału produkcyjnego $\mathrm{w}$ byłym województwie przemyskim. Ten znaczący wzrost industrializacji miasta spowodował wzmożenie napływu ludności oraz znaczące zmiany na lokalnym rynku pracy.

Istotnym wskaźnikiem tego procesu $\mathrm{w}$ obszarach wiejskich, był wzrost ludności utrzymującej się ze źródeł nierolniczych, co z kolei wywarło wpływ na poprawę ich warunków życia, a zwłaszcza w osiedlach położonych w niedalekiej odległości od miasta i wzdłuż ważniejszych szlaków komunikacyjnych. Przejawem tego była wzmożona modernizacja obiektów i rozwój budownictwa mieszkalnego oraz gospodarczego, a także doposażenie gospodarstw w sprzęt i maszyny rolnicze.

\section{ZMIANY STRUKTURALNE W PRZEMYŚLE JAROSLAWSKIM}

Proces transformacji wpłynął na zmianę w rozmieszczeniu i dostępności do zasobów technologicznych, informacyjnych, kapitałowych i surowcowych oraz ustalił nową organizację zbytu, a także źródeł zaopatrzenia (Zioło 1999). Zakłady produkcyjne poddane zostały procesom restrukturyzacji, czyli zmianom w strukturze własnościowej, zatrudnieniu, finansowaniu i zarządzaniu.

Jarosław postrzegany jest w kraju jako miasto będące modelowym przykładem udanych przedsięwzięć prywatyzacyjnych. Sprywatyzowano tu droga kapitałową trzy duże przedsiębiorstwa, a to Zakłady Przemysłu Cukierniczego „San”, Hutę Szkła „Jarosław” i Przedsiębiorstwo Przemysłu Mięsnego.

ZPC „San” sprywatyzowano przy pełnym udziale kapitału zagranicznej firmy United Biscuits z Wielkiej Brytanii, a Hutę Szkła przy udziale renomowanej firmy Owen Illinois ze Stanów Zjednoczonych Ameryki. Natomiast w odniesieniu do Zakładów Mięsnych i ZPDz. „Jarlan”, Skarb Państwa przekazał akcje spółek do Narodowych Funduszy Inwestycyjnych. 
W następstwie tego procesu sukcesywnie malało zatrudnienie w mieście i w 2003 roku osiągnęło pułap 32\% w stosunku do poziomu z 1975 roku (tab. 1). A zatem nastąpił okres regresu w potencjale produkcyjnym miasta oraz postępujący wzrost stopy bezrobocia.

\section{INICJATYWNOŚĆ WŁADZ SAMORZĄDOWYCH ORAZ MIESZKAŃCÓW}

Dobry pomysł i wiara w sukces przedsięwzięcia oraz skuteczna strategia rozwoju, to warunki umożliwiające uzyskanie zamierzonego celu. W takich uwarunkowaniach wyzwoliły się inicjatywy wśród samorządu lokalnego i mieszkańców miasta zmierzające do aktywizacji życia społeczno - gospodarczego.

W 2003 roku uzyskano listy intencyjne Wolnej Strefy Ekonomicznej „Euro-Park Mielec" na uruchomienie produkcji foteli do samochodów osobowych firmy Fiat w zwolnionych halach produkcyjnych ZPDz. „Jarlan”. Wymienioną produkcję rozwija znana z wytwarzania akcesoriów do samochodów osobowych firma Lir Corporation Poland przy wstępnym zatrudnieniu 350 osób, a docelowo 750 osób. Dla potrzeb tej produkcji przeszkolono 120 osób w zawodach szwaczka i krajczy. Równocześnie w wolnych obiektach Zakładów Zbożowych PZZ organizowana jest kolejna firma branży olejarskiej, która zatrudni około 300 osób.

Ponadto prowadzone są negocjacje zmierzające do budowy w Jarosławiu pierwszej ekologicznej elektrowni w kraju na bazie miejscowych złóż gazu ziemnego o mocy 120 MW. To zadanie inwestycyjne ma sfinansować angielska firma Intern Generation, co przysporzy kolejną pulę nowych miejsc pracy.

Bardzo wymierna inicjatywą było zaangażowanie na rzecz utworzenia $\mathrm{w}$ mieście wyższej uczelni. Głównymi przesłankami na rzecz powołania placówki akademickiej w znaczącym ośrodku szkolnictwa średniego były:

- dobra lokalizacja miasta w stosunku do wschodnich i południowych obszarów województwa lubelskiego oraz wschodnich i południowych rejonów Podkarpacia,

- bardzo dobre położenie Jarosławia na szlakach komunikacji drogowej i kolejowej,

- praktyczna możliwość przejęcia obiektów po zlikwidowanej w centrum miasta jednostce wojskowej, jako niezbędnej bazy dydaktycznej dla przyszłej uczelni.

Efektem wielorakich działań było rozpoczęcie kształcenia na poziomie wyższym w Jarosławiu z dniem 1 października 1998 roku (tab.2).

Tab. 2 Państwowa Wyższa Szkoła Zawodowa w Jarosławiu.

\begin{tabular}{|c|l|c|c|}
\hline Rok & \multicolumn{1}{|c|}{ Specjalność kształcenia } & $\begin{array}{c}\text { Liczba } \\
\text { studentów }\end{array}$ & $\begin{array}{c}\text { Liczba nauczycieli } \\
\text { akademickich }\end{array}$ \\
\hline 1998 & $\begin{array}{l}\text { - Gospodarka turystyczna i hotelarstwo } \\
\text { - Ekonomika gospodarki żywnościowej } \\
\text { - Rachunkowość i finanse przedsiębiorstw }\end{array}$ & 685 & 37 \\
\hline 2000 & j. w. & 4120 & 112 \\
\hline 2003 & $\begin{array}{l}\text { dodatkowo: } \\
\text { - Informatyka stosowana } \\
\text { - Pielęgniarstwo }\end{array}$ & 10350 & 286 \\
\hline
\end{tabular}

Źródło: Dział Kadr PWSZ

Dane w tabeli potwierdzają bardzo dynamiczny rozwój analizowanej placówki akademickiej. Następstwem funkcjonowania Uczelni w Jarosławiu jest:

- wzrost pozycji miasta w regionie (wzbogacenie dotychczasowego wizerunku),

- $\quad$ skrócenie drogi kształcenia i obniżenie jego kosztów dla części młodzieży, a zwłaszcza o niskich dochodach rodzinnych, 
- wzmocnienie rynku pracy w mieście,

- poprawa kondycji finansowej Przedsiębiorstwa PKS,

- wzrost dochodów mieszkańców w tytułu wynajmu kwater, zwiększonych obrotów w punktach sprzedaży artykułów spożywczych, szkolnych itp.

- zagospodarowanie substancji lokalowej po byłej jednostce wojskowej i zakładach drzewnych (poprawa wystroju architektonicznego).

W 2003 roku miasto Jarosław z liczbą 42 tys. mieszkańców posiada wyższą uczelnię, w której kształci się powyżej 8 tys. studentów w systemie studiów stacjonarnych i 3 tys. w systemie zaocznym. Wspólnie z Hutą Szkła stanowi najważniejszy czynnik miastotwórczy decydujący o jego wzroście społeczno-gospodarczym i nobilitujący gród nad Sanem $\mathrm{w}$ przestrzennym zagospodarowaniu regionu podkarpackiego.

\section{LITERATURA}

Drucker P. F., 1992. Innowacja i przedsiębiorczość. Praktyka i zasady. PWE. Warszawa.

Makieła Z., Rachwał T., 2002. Podstawy przedsiębiorczości. Program nauczania. Wydawnictwo. Nowa Era. Warszawa.

Makieła Z., Rachwał T., 2005. Podstawy przedsiębiorczości. Podręcznik. Wyd. IV, Wydawnictwo Nowa Era. Warszawa.

Penc J., 1999. Innowacje $i$ zmiany $w$ firmie. Transformacje $i$ sterowanie rozwojem firmy. Agencja Wydawnicza PLACED. Warszawa.

Piasecki B., 1992. Polityka rozwoju małych i średnich przedsiębiorstw w państwach centralnej $i$ wschodniej Europy. Międzynarodowy Kongres Małego Biznesu. Warszawa.

Rościszewski M., 1997. Polska granica wschodnia. Geopolitical Studien. Wol. 1. Instytut Geografii i Przestrzennego Zagospodarowania PAN. Warszawa.

Zioło Z., 1999. Transformacja struktur regionalnych Polski poludniowo-wschodniej w okresie zmian systemu gospodarowania. Prace Komisji Nauk Ekonomicznych. PAN Oddział w Krakowie. Kraków. 